\title{
Labio inflamado: una reacción no mediada por la histamina
}

\author{
Swollen lip: a reaction not mediated by histamine
}

\section{CASE REPORT}

We present a case of a 54-year-old-woman admitted to the emergency room with swollen upper lip with 1 day of evolution. Her family doctor prescribed the day before oral antihistamine and corticoid, with no improvement. She denied any allergies, dyspnoea, hoarseness, cutaneous rash, fever, new drugs, or new diet. Her past medical history was relevant for arterial hypertension, controlled with an angiotensin-converting enzyme inhibitor (ACE inhibitor), started about 2 years ago. Physical examination showed only upper lip oedema (figures 1 and 2), without signs of urticarial rash, tongue enlargement, bronchospasm, or hypotension. At first approach it was started treatment with IV clemastine and hydrocortisone, with no improvement after 4 hours. Referred to the use of an ACE inhibitor, angioedema induced by this drug was suspected. Due to that fact, ACE inhibitor was suspended and after 72 hours the oedema vanished.

Angioedema is a potentially fatal adverse effect, sometimes seen in patients taking ACE inhibitors, with an incidence of $0.1-0.7 \%$. It shows as oedema of the lips, tongue, face, upper airway, and occasionally gastric mucosa. This type of angioedema is believed to be caused by an increase in bradykinin (secondary to ACE inhibitor), which is a potent vasodilation mediator ${ }^{1}$. It can progress in minutes to hours with resolution between 24 to 72 hours $^{2}$.

The treatment consists in mandatory suspension of ACE inhibitor and supportive treatment. Sometimes requires airway protection and mechanical ventilation until clinical improvement ${ }^{3}$. Antihistamines, corticosteroids, or adrenaline are not effective, since ACE inhibitor induced angioedema is not mediated by histamine ${ }^{4}$.

Although angioedema induced by ACE inhibitor is described on literature, its incidence is low. We must keep this side effect in mind because it seems like an allergic reaction or anaphylaxis but does not respond to the same treatment. The suspension of ACE inhibitor must be promptly to avoid a fatal outcome.

\section{REFERENCES}

1. Guyer AC, Banerji A. ACE inhibitor-induced angioedema. UpToDate. 2020. https:// www.uptodate.com/contents/ace-inhibitor-induced-angioedema.

2. Banerji A, Clark S, Blanda M, LoVecchio F, Snyder B, Camargo CA Jr. Multicenter study of patients with angiotensin-converting enzyme inhibitor-induced angioedema who present to the emergency department. Ann Allergy Asthma Immunol. 2008;100(4):327-332.

3. Chan NJ, Soliman AM. Angiotensin converting enzyme inhibitor-related angioedema: onset, presentation, and management. Ann Otol Rhinol Laryngol. 2015;124(2):89-96.

4. Brown T, Gonzalez J, Monteleone C. Angiotensin-converting enzyme inhibitorinduced angioedema: A review of the literature. J Clin Hypertens (Greenwich). 2017;19(12):1377-1382.

Palabras clave: inhibidor de la ECA (enzima convertidora de la angiotensina), angioedema, reacción farmacológica, bradicinina

Keywords: ACE inhibitor (angiotensin-converting enzyme), angioedema, drug reaction, bradykinin
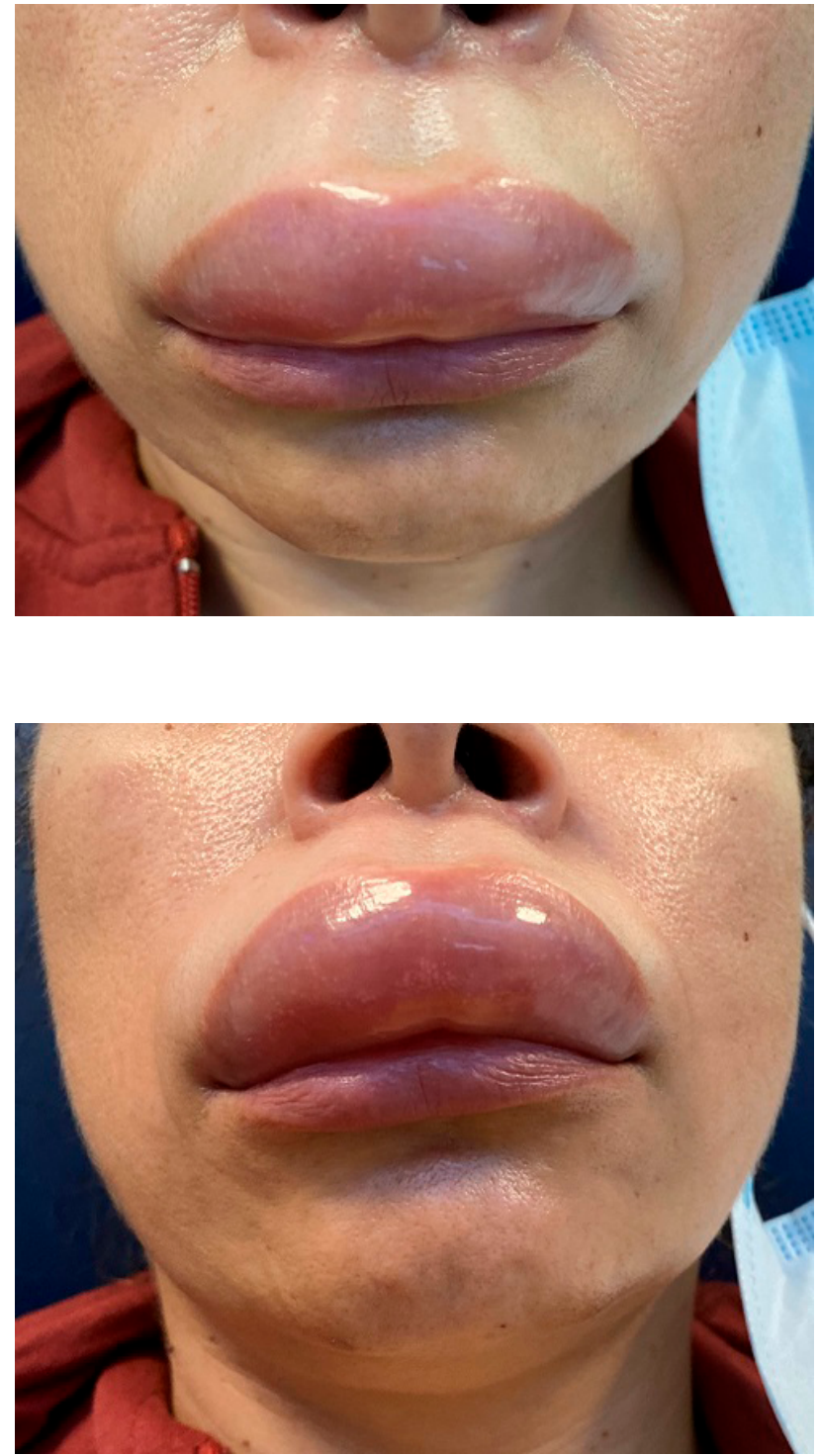

Telma Elias ${ }^{1}$, Ana Clara Dinis ${ }^{1}$

${ }^{1}$ Centro Hospitalar do Médio Tejo, Abrantes, Portugal

Correspondencia: telma.p.elias@gmail.com

Cómo citar este artículo: Elias T, Dinis AC

Labio inflamado: una reacción no mediada por la histamina. Galicia Clin 2021; 82-4: 240

Recibido: 21/12/2020; Aceptado10/3/2021 // https://doi.org/10.22546/63/2430 